\title{
RESEARCH INTO SOME ECONOMIC ASPECTS RELATED TO EMIGRATION: THE CASE OF SLOVAKIA AND LATVIA
}

\author{
Irēna SILINEVIČA ${ }^{1}$, Ivana SLOVÍKOVÁ2 \\ ${ }^{1}$ Dr.sc.ing., professor at the Faculty of Economics and Management, \\ Rezekne Higher Education Institution, Rezekne, Latvia \\ e-mail: irena.silinevica@ru.lv, phone: +371 29103480, \\ 2 Slovak University of Agriculture in Nitra, Nitra, Slovakia \\ e-mail: ivana.slovicka@gmail.com, phone +421902 632959
}

\begin{abstract}
The common problem in the EU countries is a high rate of youth unemployment. Many well- educated young people emigrate from their native countries with the aim to look for better job opportunities abroad. Slovakia and Latvia are the countries with a high rate of youth emigration. The major reason for emigration is the economic situation in both countries - high rate of unemployment and low wages. Usually emigrants from these countries are employed as unskilled workers abroad. Thereby the native countries of emigrants lose well-educated people but the destination countries of migrants do not exploit the skills and knowledge of these people. In this case this problem is a social problem at the EU level. The aim of this research study is to evaluate and to compare the economic situation in Slovakia and Latvia, as well as in the destination countries of migrants. Suggestions referred to the decrease in human capital flight or brain drain from Latvia and Slovakia are presented in this paper. The main sources exploited in the analysis embrace the European statistical database and the statistical databases of the Slovak Republic and the Republic of Latvia. This research focuses on the annual data of two countries covering a period of 2004-2014. The year 2004 for both countries is the year of their accession to the EU. The main research methods employed in this study are as follows: comparison analysis, statistical analysis, content analysis.
\end{abstract}

Keywords: economies of Latvia and Slovakia, unemployment, minimum wages, GDP JEL code: $A 10, E 24$

\section{Introduction}

There are substantial differences that exist in European labour markets, welfare systems, and recent migration flows. People move across countries for many reasons. Economic theory most prominently highlights the international labour mobility that descends from wage differences across countries. Many students from developing economies migrate to advanced countries, for either short or long durations, to study in the schools and universities of advanced countries (e.g. Borjas, 2009).

Sari Pekkala Kerr and William R. Kerr investigated the economic impacts of immigration in various host countries and the assimilation of immigrant workers into host-country labour markets and concomitant 
effects for natives. They investigated the use of social benefits by immigrants as well: as immigrants are more often outside of the labour force or unemployed, it has been assumed that they spend more time on welfare and other forms of social assistance compared to natives. Migrants frequently look for higher income levels, better personal safety, short distance to home countries, and established immigrant networks as the main reasons for choosing their new host countries (e.g. Kerr, 2013).

Econometric studies tend to support the importance of income differentials, which is also evident in comparisons of income or GDP levels between host and source countries. Some empirical studies estimate the fiscal impacts of immigration: there certainly exist large differences across migrant groups in the costs and benefits they cause for a host country; the net impact depends heavily on the migrants' age, education, and duration of stay (e.g. Dustman, 2008). Enlargement of the $\mathrm{EU}$ and the opening up of borders encourage economic migration of population (Terenzami, 2014).

Slovakia and Latvia are the countries with a high rate of youth emigration. The most significant reason for emigration is the economic situation in both countries: a high unemployment rate and low wages. People from Latvia and Slovakia most often emigrate to Ireland, the United Kingdom, and Germany. For people from Slovakia, the most popular host countries are the Czech Republic and Austria.

The findings elicited from various studies on the emigration problems in Latvia underline the fact that these problems are very significant in Latvia and they are to be solved at the governmental level. Hazans M. (2011) emphasizes that the main emigration segments during the research period were in the following age group 15-24. Apsite-Berina, E (2013) denoted that more than 120 thousand inhabitants of Latvia had emigrated to the UK in 2004-2012. Ireland, the UK, and Germany are the main destinations of labour from Latvia (Hazans, 2012). Many researchers have indicated the need for the establishment of organizations which deal with the monitoring and regulation of international migration where policy can effectively manage it at the central rather than the local level (Andrasova, 2014).

The aim of this research study is to evaluate and to compare the economic situation in Slovakia and Latvia as well as in the destination countries of migrants, and to develop proposals to reduce the emigration flow from these countries.

To accomplish the aim of the research study, several objectives have been defined:

- to compare the changes in some macroeconomic figures of Slovakia and Latvia with the changes on average in the EU; 
- to compare the changes in some macroeconomic figures for Slovakia and Latvia with the changes in figures for host countries of emigrants;

- to develop proposals to reduce the youth emigration flow from both countries.

The hypothesis of this research: it is possible to reduce the youth emigration flow from both countries by changing the approach to youth policy at the governmental level.

The main research methods are as follows: the descriptive method was employed to interpret the research results based on the scientific findings and theories; analysis and synthesis were used to examine individual problem elements and identify connections among them; induction was exploited to make scientific assumptions and identify a causal relationship of individual elements or facts; deduction was employed to logically systematise and explain the statistical data.

\section{Research results}

\section{Comparison of changes in GDP in Latvia and Slovakia with changes on average in the $E U$}

A comparison of annual GDP changes in Latvia, Slovakia and the changes on average in the EU is reflected in Table 1 . Since the end of 2009, the economic recession in Latvia stopped and the growth resumed. From 2011 to 2013, the GDP increased on average by 4.7\% per year, which was one of the highest growth rates in the EU (Baranovs, 2014). Regardless of the fact that the economy of Latvia has been growing in the recent years, the GDP is still $5.3 \%$ lower than before the downturn in 2007. Slovakia recovered from the economic crisis, as it was one of the strongest and fastest-growing economies in the European Union, but the recovery of domestic demand lingered as both private consumption and investment stayed below their 2008 levels in real terms (Morway, 2013). In 2014 the domestic demand in Slovakia recovered and continued to grow at a faster pace. According to the Slovak statistical database of 2015, the real GDP grew by $3.5 \%$ in 2014 as compared with $1.4 \%$ in 2013 (see Table 1).

Table 1 Annual GDP changes (\%) in Latvia,

Slovakia and the average in the EU

(Source: compiled by the authors [17] [24])

\begin{tabular}{|l|l|l|l|l|l|l|l|l|l|l|l|}
\hline Years & 2004 & 2005 & 2006 & 2007 & 2008 & 2009 & 2010 & 2011 & 2012 & 2013 & 2014 \\
\hline Latvia & 8.9 & 10.2 & 11.6 & 9.8 & -3.2 & -14.2 & -2.9 & 5.0 & 4.8 & 4.2 & 2.4 \\
\hline Slovakia & 5.2 & 6.5 & 8.3 & 10.7 & 5.4 & -5.3 & 4.8 & 2.7 & 1.6 & 1.4 & 2.4 \\
\hline $\begin{array}{c}\text { Average } \\
\text { in EU }\end{array}$ & 2.5 & 2.0 & 3.4 & 3.1 & 0.5 & -4.4 & 2.1 & 1.7 & -0.5 & 0.0 & 1.3 \\
\hline
\end{tabular}




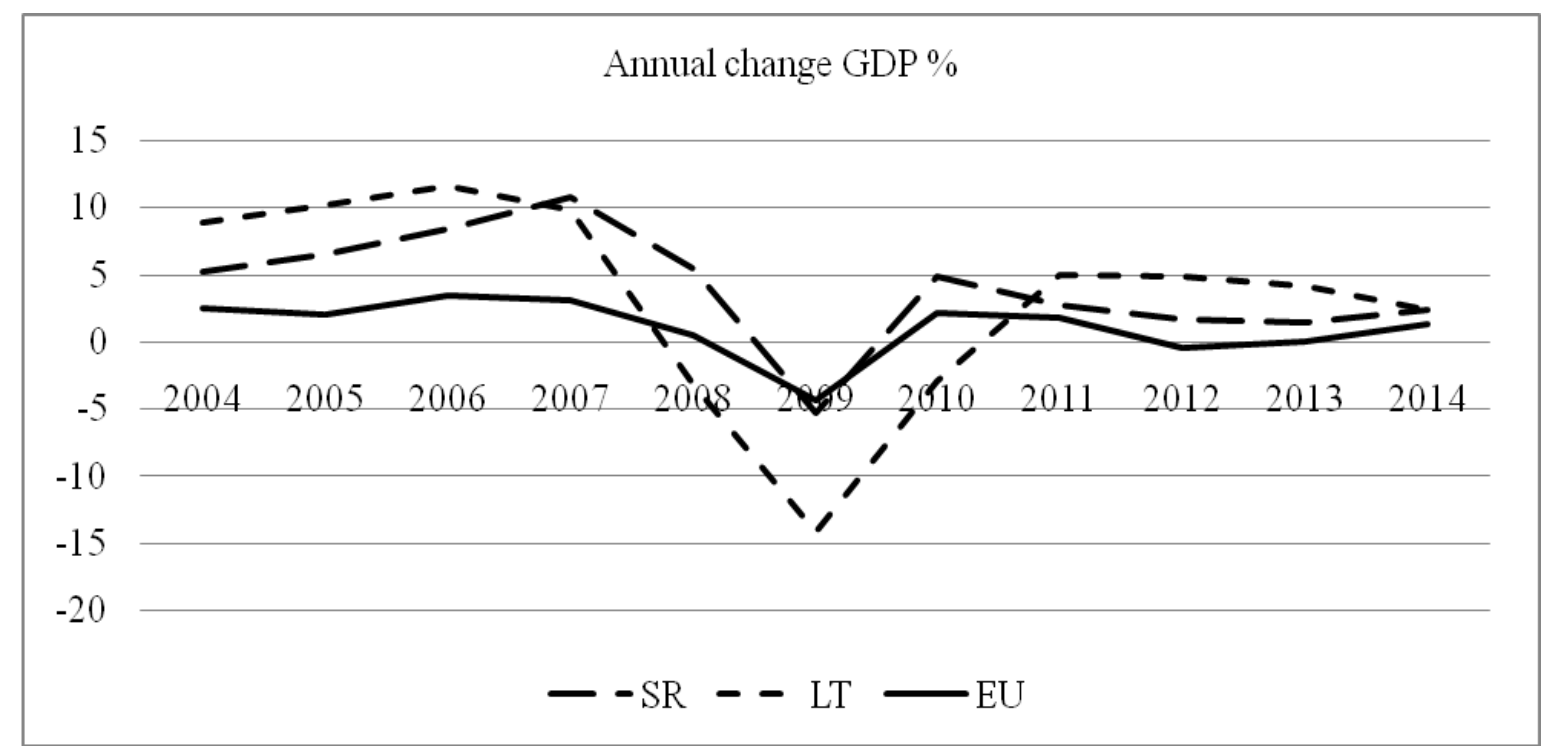

Fig.1 Comparison of annual GDP changes in Latvia, Slovakia and the average in the EU (Source: compiled by the authors [17] [24])

The analysis of data (Fig.1) shows the dynamics of annual changes in the GDP in both countries and the average in the EU. The biggest annual changes in the GDP were from 2008 to 2010 because of the economic downturn in economies. The positive changes have taken place in Latvia and Slovakia since 2010. The changes in the GDP were higher than on average in the EU. The positive trends remained steady during the last 4 years.

\section{Comparison of the rates of unemployment in Latvia and Slovakia with the average in the $\mathrm{EU}$}

The gradual improvement of the economic situation also positively affected the situation in the labour market - unemployment decreased. Since 2010 the number of the employed has increased gradually. The increase in employment is due to the recovery of economies. The current unemployment rate is mainly related to the cyclical unemployment.

In Slovakia the unemployment rate remained high at over 13\%, despite the growth of employment throughout 2014. The labour market conditions were projected to improve together with the recovery in the economic activity. Long-term unemployment is a constant problem in Slovakia. (Terenzani, 2015) 
Table 2 The rates of unemployment (\%) in Latvia,

Slovakia and the average in the EU

(Source: compiled by the authors [17] [24])

\begin{tabular}{|l|l|l|l|l|l|l|l|l|l|l|l|}
\hline Years & 2004 & 2005 & 2006 & 2007 & 2008 & 2009 & 2010 & 2011 & 2012 & 2013 & 2014 \\
\hline Latvia & 11.7 & 10.0 & 7.0 & 6.1 & 7.7 & 17.5 & 19.5 & 16.2 & 13.9 & 11.5 & 10.5 \\
\hline Slovakia & 13.1 & 11.4 & 8.0 & 8.0 & 3.5 & 12.1 & 14.4 & 13.6 & 14.0 & 14.2 & 12.3 \\
\hline $\begin{array}{l}\text { Average } \\
\text { in EU }\end{array}$ & 9.3 & 9.0 & 8.3 & 7.2 & 7.1 & 9.0 & 9.7 & 9.7 & 10.5 & 10.8 & 12 \\
\hline
\end{tabular}

The lowest unemployment rate in Latvia was in 2007, and the highest unemployment rate was in 2010. After 2011 the unemployment rate in Latvia decreased gradually. In Slovakia the lowest unemployment rate was in 2008, and the highest unemployment rate was in 2013.

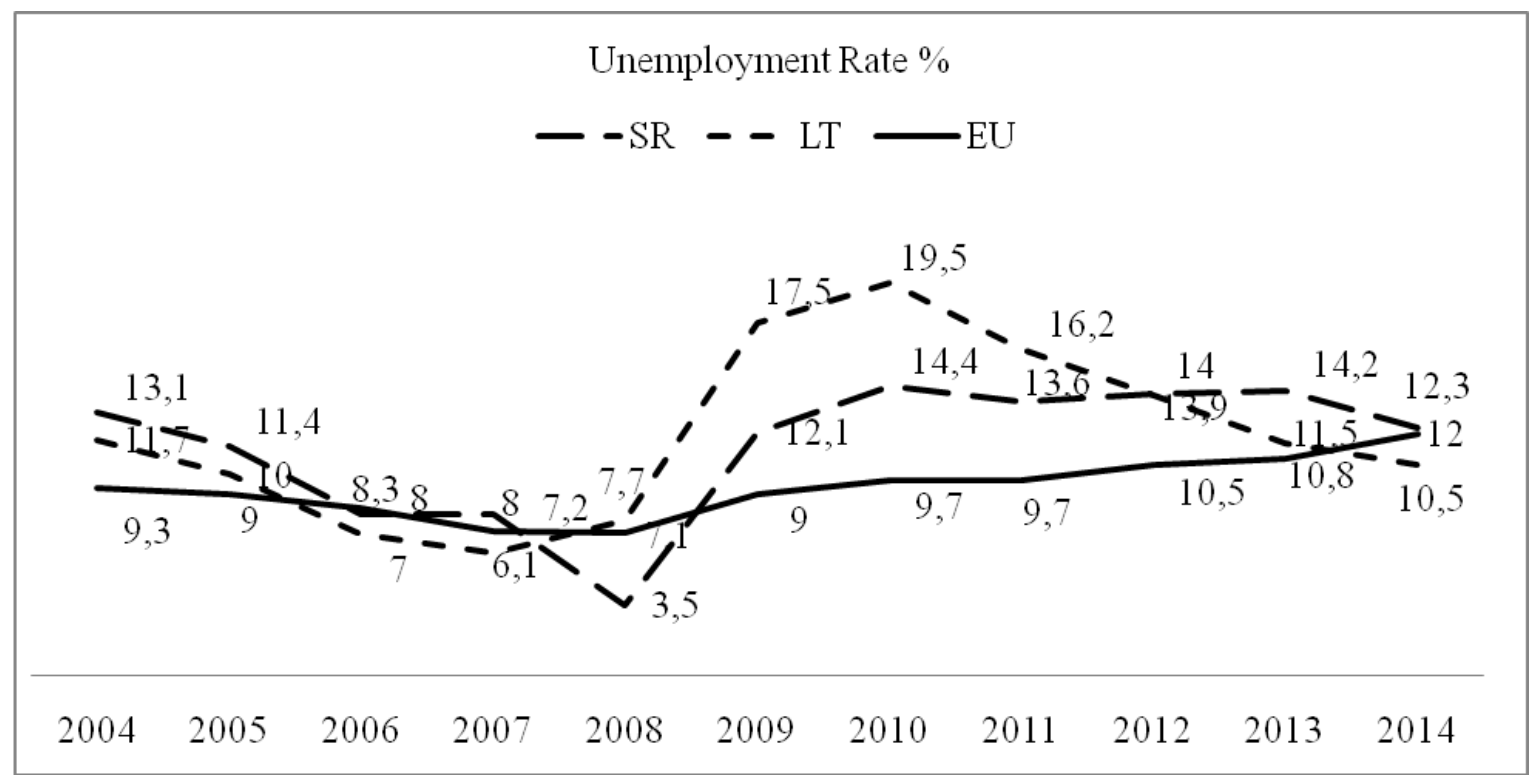

Fig.2 The rates of unemployment (\%) in Slovakia,

Latvia and the average in the EU

(Source: compiled by the authors [17], [24])

From 2010 to 2013, the unemployment rate in Slovakia changed slightly, remaining at around 14\% (see Fig.2). Improvement in the labour market conditions was closely connected with the development of economic activities. Long-term unemployment is a constant problem in Slovakia and Latvia.

\section{Comparison of the inflation rates in Latvia and Slovakia with the average in the $\mathrm{EU}$}

The rates of inflation in Slovakia and Latvia were higher than on average in the $\mathrm{EU}$ in 2004. After the accession to the $\mathrm{EU}$, the inflation rate 
in Slovakia decreased and approached the average in the EU until 2013, and in 2014 - the deflation reached $0.1 \%$.

Table 3 The rates of inflation (\%) in Latvia, Slovakia and the EU average (Source: compiled by the authors [17] [24])

\begin{tabular}{|l|l|l|l|l|l|l|l|l|l|l|l|}
\hline Years & 2004 & 2005 & 2006 & 2007 & 2008 & 2009 & 2010 & 2011 & 2012 & 2013 & 2014 \\
\hline Latvia & 6.2 & 6.7 & 6.5 & 10.1 & 15.4 & 3.5 & -1.1 & 4.4 & 2.2 & 0.1 & 0.8 \\
\hline Slovakia & 7.5 & 3.7 & 4.2 & 3.4 & 4.6 & 0.9 & 0.7 & 4.1 & 3.6 & 1.4 & -0.1 \\
\hline $\begin{array}{l}\text { Average } \\
\text { in EU }\end{array}$ & 2.0 & 2.2 & 2.2 & 2.3 & 3.7 & 1.0 & 2.1 & 3.1 & 2.6 & 1.5 & 0.6 \\
\hline
\end{tabular}

A different situation was faced in Latvia - the inflation rate was much higher than on average in the EU, and in 2008 it reached $15.4 \%$. In 2009 it decreased sharply to $3.5 \%$ and until 2013 the inflation rate in Latvia was much lower than on average in the EU (see Table 3).

\section{Comparison of changes in gross wages in the source and host countries of migrants}

The average gross wage in Latvia grew by $4.6 \%$ in 2013, as compared to the previous year, and reaching EUR 716. In 2013, it was 5 $\%$ higher than before the downturn in 2008 (Table 4). The average gross wages in both countries are presented in Figure 3. The average gross wage in Slovakia grew by $1.2 \%$ in 2013, as compared to the previous year, reaching EUR 969.1. In 2013, it was 16.3\% higher than before the downturn in 2008. One of the reasons why not only young but also elderly people emigrate from Slovakia is low wages. People emigrate from Slovakia as they are trying to find better paid jobs abroad. Elderly people, especially women, move to Germany or Austria because social security for elderly people in these countries is higher than in Slovakia. Young people who decided not to continue their education in universities emigrate to the UK, Germany, the Czech Republic and Spain. After graduation, a lot of students emigrate because they do not see the opportunities to find any jobs in Slovakia. A similar situation is also encountered in Latvia.

In both countries, the average monthly wage grew gradually (see Fig.3). According to the statistics, the average wage in Slovakia was higher than in Latvia. A forecast was also positive. 


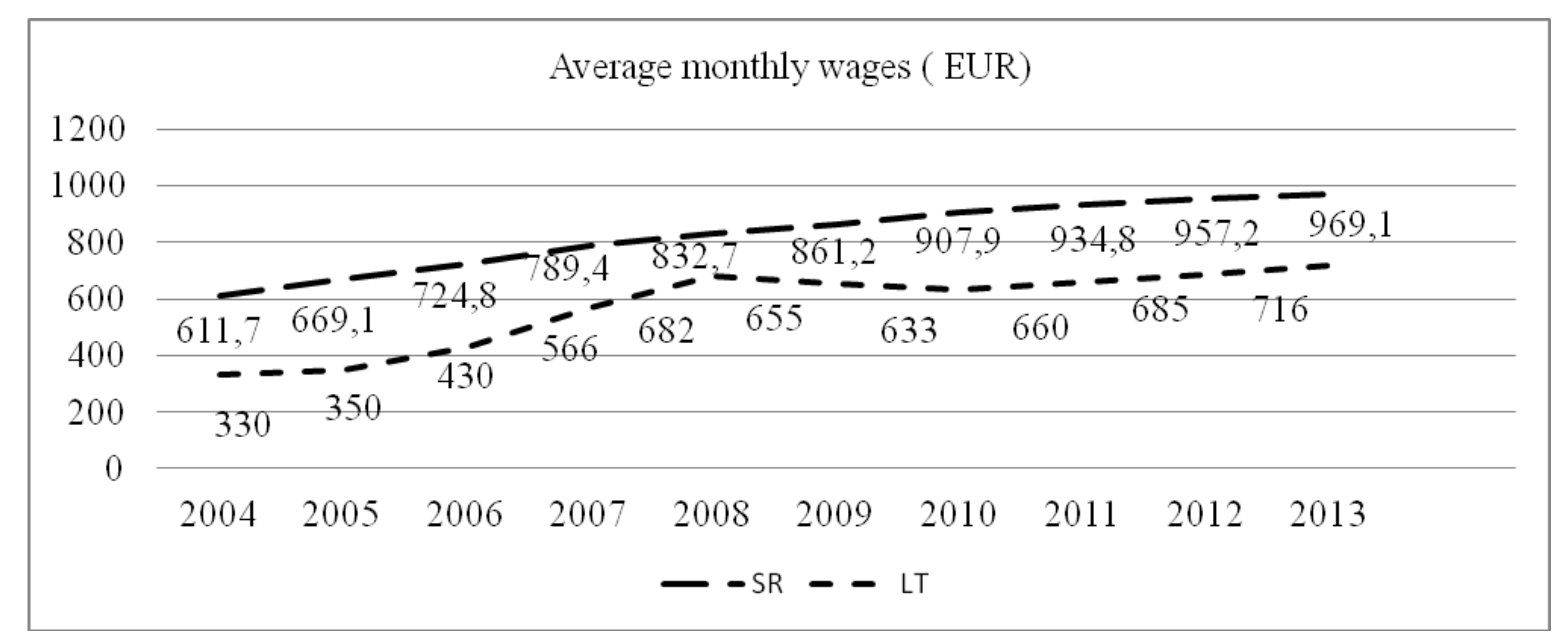

Fig. 3 The average gross wages in Slovakia and Latvia (Source: compiled by the authors [17] [24])

The average monthly wage in the EU in 2012 was EUR 2,746 [24]. It means that the average wage in the EU was 3 times higher than in Slovakia or Latvia (Table 4). The average monthly wage in the UK in 2013 was EUR 3,663 and in Ireland it was EUR 3,948.8. It means that in the UK and Ireland, on average, wages were at least 4 times higher than in Slovakia and Latvia (Table 4).

Table 4 Gross average monthly wages in Ireland, the UK,

Slovakia and Latvia, EUR

(Source: compiled by the authors [17] [18] [19] [24])

\begin{tabular}{|l|l|l|l|l|l|l|l|l|l|l|}
\hline Country & 2004 & 2005 & 2006 & 2007 & 2008 & 2009 & 2010 & 2011 & 2012 & 2013 \\
\hline Ireland & $3,331.8$ & $3,524.6$ & $3,662.5$ & $3,873.4$ & $4,029.5$ & $4,125.4$ & $3,985.2$ & $3,980.8$ & 4,017 & $3,948.8$ \\
\hline UK & 2,919 & 2,977 & 3,126 & 3,277 & 3,336 & 3,400 & 3,478 & 3,545 & 3,609 & 3,663 \\
\hline SR & 611.7 & 669.1 & 724.8 & 789.4 & 832.7 & 861.2 & 907.9 & 934.8 & 957.2 & 969.1 \\
\hline LT & 330 & 350 & 430 & 566 & 682 & 655 & 633 & 660 & 685 & 716 \\
\hline
\end{tabular}

Most people would like to see prospects for the development in their own countries and the economic well-being is not the only factor which makes them happy. Taking into account only the economic reasons, the positive solution to the youth emigration problem is not possible for at least next 30-40 years.

David Bartram (2013) explored the feelings of economic migrants happiness among migrants and stayers in a number of European countries, investigating individuals from East European countries who went to Western Europe. The researcher noted that life in wealthier countries might be better, particularly for migrants who succeed in 
improving their financial situation, but in general, people do not gain happiness from an increase in their incomes.

The consequences of emigration of well-educated people from the country are as follows: the country will not return the investments, which are used for the purpose of educating and training the young people who decide to leave the country after graduation; the intellectual potential and human capital of the country decreases.

A lot of students who decide to go abroad just in the frame of students' mobility programmes to gain new experience can look for possibilities after their mobility to stay abroad if they prefer working in another country.

The government of the Slovak Republic has suggested some ways to keep educated people in their own country, especially by creating more jobs for educated people, for example, by attracting investors who would increasingly employ highly skilled young people, providing more lowcost mortgages for young people, raising wages at universities and in the public sector, investing in research and development, providing tax relief for migrants returning to and investing in Slovakia and to provide a better education at Slovak universities.

The EU is a very important supporter of young people. The EU aims to raise the awareness of global issues among the young, to provide opportunities to exchange views with policy makers to foster mutual understanding, encourage the young to volunteer, promote entrepreneurship, employment, education and volunteering opportunities. There are the projects intended to support young people. For instance, Erasmus + project meant to support international mobility and international cooperation. These projects help young people become more active and more exposed to employment opportunities through education. Other possibilities are the cooperation with EU neighbouring partners, bilateral events between the EU and non-EU countries, which strive to promote intercultural dialogue and understanding between young people. The EU has produced a number of joint partnership projects focusing on issues of common interest such as employability and entrepreneurship, youth involvement in society, and voluntary activities. There is also a social programme of the European Union, from which Slovakia can use EUR 200 million in 2014 and 2015, which can be used to create jobs or to retrain young unemployed people. The aim of the upcoming project is to provide a chance for young people to find a job offer within four months after graduating, or a chance for further training or retraining. Latvia is participating in the EU Employment and Social Innovation Programme 2014-2020, which provides a very significant financial (around EUR 900 million) support. 


\section{Conclusion and suggestions}

Latvia and Slovakia are the countries that are considered to be the countries with the lowest wages in the European Union. The rate of unemployment in these countries is higher than the average rate of unemployment in the EU, and the wages are lower than the average in the EU. The statistical data of Latvia and Slovakia show that people from both countries have emigrated to Ireland, the UK, and Germany because of higher wages and higher possibility to find a job. The consequences of emigration of well-educated people from the country are as follows: the country will not return the investments, which are used for the purpose of educating and training of these young people who decide to leave the country after graduation, the intellectual potential and human capital of the country decreases.

Each country should do its best to save the intellectual potential because human resources are the main source of country's development. Successful development of a country depends on knowledge, skills and competencies of human resources available in this country. The solution to the migration problem requires a strategic approach at the national level. It is necessary to develop a Human Resource Development Programme at the national and regional levels with the aim to create the interest of local people regarding business opportunities in their native regions. A high-quality Human Resource Development Programme and its successful implementation could also prevent the depopulation threats emerging in the region. One of the strategic directions of the Human Resource Development Programme should be training of young people. This training should be associated with specializations of the region in order to develop an awareness and interest of young people regarding their business opportunities in their own regions.

Creation of jobs will help to prevent youth emigration by using all the opportunities of the EU programmes which are related to youth employment.

Economic development requires a lot of well-educated employers. In this regard, labour education and training in Latvia and Slovakia should be changed to the following direction: graduates should be ready to become employers, not only employees. It is necessary to change the approach to teaching programmes already at an early stage of education with the aim to discover and develop new talents for business. The approach has to be shifted from preparing employees to preparing employers. 


\section{References}

1. ANDRASOVA, S. (2013): Načo nám je dobrá migrácia? Retrieved March, 20, 2015 from http://www.cpep.sk/fileadmin/Dokumenty/publikacie/migracia/ Andrasova-Migracia.pdf

2. APSITE-Berina, E. (2013). Starpvalstu migrācija Eiropas Savienībā: Latvijas iedzīvotāju migrācija uz Lielbritāniju. Promocijas darba kopsavil kums Doktora zinātniskā grāda iegūšanai ǵeogrāfijas nozarē, LU, Rīga, 2013.

3. Bartram David (2013) Happiness and 'economic migration': A comparison of Eastern European migrants and stayers .Oxford Journals, Social Sciences, Migration Studies. Volume 1, Issue 2, pp. 156-175

4. BORJAS G. (2009) Immigration in high-skill labor markets: The impact of foreign students on the earning of doctorates, in Freeman R. \& Goro§ D. (eds.) Science and Engineering Careers in the United States: An Analysis of Markets and Employment, University of Chicago Press, Chicago

5. DUSTMANN C., Glitz A. \& Frattini T. (2008) The labour market impacts of immigration, Oxford Review of Economic Policy, 24, 3, 477-494

6. FONTINELLE, A.(2011). Standard of Living Vs. Quality Of life. Retrieved in March 17, 2015 form < http://www.investopedia.com/articles/financialtheory/08/ standard-of-living-quality-of-life.asp>

7. HAZANS, M (2011). The changing face of Latvian emigration, 2000-2010. In: B.Zepa and E. Klave (eds), "Latvia. Human Development Report 2010/2011: National Identity, Mobility and Capability". Riga: Univ. of Latvia Press: 70-91

8. Hazans, M (2012). Selectivity of migrants from Baltic countries before and after enlargement and responses to the crisis.. Intra-EU Migration in Troubled Times: Skills Mismatch, Return Migration and Policy Responses. Farnham, UK: Ashgate.

9. King,M (2015). The Daily.sk Retrieved in March 18, 2015 from http://www.thedaily.sk/slovakia-business-forecast/

10. Kišš, Š - Šiškovič, M.(2006). Porovnanie životnej úrovne na Slovensku v rokoch 1989 - 2005. Retrieved in March 20, 2015 from <http://www.finance.gov.sk/ Documents/Ifp/Publikacie/Makro/ EA11_ZIVOTNA

11. Markova, J. (2010). Nárat počtu bankrotov a neuhradených záväzkov pokračuje aj v prvom kvartáli roku 2010. Finančný manažér 2/X. , 58-67

12. Mmorvay,K(2013). Economic Development of Slovakia in 2012 and Outlook up to 2014. In Ekonomicky casopis/Journal of Economics. Vol. 61, no. 8 (2013), p. 767-845.

13. Sari Pekkala Kerr, William R. Kerr (2013) Economic Impacts ofImmigration: A Survey, Harward Business school 2013

14. Terenzani,M. (2014)The Slovak Spectator. Retrieved in March 18, 2015 from http://spectator.sme.sk/c/20056643/slovaks-need-to-open-up-toimmigrants.html

15. Zahraničná politika Slovenskej republiky. Výročná správa za rok 2010. Bratislava:Ministerstvo zahraničných vecí. Retrieved in March 21,2015 from http://www.mzv.sk/App/wcm/media.nsf/vw

16. Sk Today - report Retrieved in March 19, 2015 from http://www.sktoday.com/ content/2194_slovaks-perceive-unemployment-most-serious-social-problem

17. Country report Latvia (2015). Retrieved March 20, 2015, from http://ec.europa.eu/europe2020/europe-2020-in-your-country/latvija/

18. Country repost UK (2015). Retrieved March 20, 2015 from, http://ec.europa.eu/europe2020/pdf/csr2015/cr2015_uk_en.pdf 
19. Country report Ireland (2015). Retrieved March 21,2015 from http://ec.europa.eu/europe 2020 /pdf/csr2015/cr2015_ireland_en.pdf

20. Doing Business (2006). Creating Jobs. A copublication of the World Bank and the International Finance Corporation, ISBN 0-8213-5749-2

21. Economic-surveys-Latvia-2015.Retrieved in March 18, 2015 from http://www.keepeek.com/Digital-Asset-Management/oecd/economics/oecdeconomic-surveys-latvia-2015_9789264228467-en\#page5

22. Doing Business (2007). How to reform. A copublication of the World Bank and the International Finance Corporation, ISBN 0-8213-6488-X

23. The Government Office Of The Slovak Republic. Retrieved in March 20,2015 from www.vlada.gov.sk/uliha-statu-a-verejneho-sektora/

24. Statistical Office of the Slovak Republic : Retrieved in March 18, 2015 from < http://portal.statistics.sk/showdoc.do?docid=4>

\section{DAŽU EKONOMISKO ASPEKTU IZPĒTE SAISTĪBĀ AR EMIGRĀCIJU: SLOVĀKIJAS UN LATVIJAS PIEMĒRS}

\section{Irēna SILINEVIČÁ1, Ivana SLOVÍKOVÁ ${ }^{2}$}

1 Dr.sc.ing., Rēzeknes Augstskolas, Ekonomikas un pārvaldības fakultātes profesore, Rèzekne, Latvija

${ }^{2}$ Slovākijas Lauksaimniecības uiniversitāte Nitrā, Nitra, Slovākija

\section{Kopsavilkums}

ES valstu kopējā problēma ir augsts bezdarba līmenis jauniešu vidū. Daudzi labi izglītoti jaunieši emigrē no savām valstīm ar mērḳi atrast darba iespējas ārzemēs. Slovākija un Latvija ir valstis, kurās ir sevišksi augsts jauniešu emigrācijas līmenis. Kā rāda pētījumi, galvenais emigrācijas cēlonis ir ekonomiskā situācija valstī - augsts bezdarba līmenis un zemas algas. Visbiežāk jaunieši no abām valstīm emigrē uz tādām valstīm, kā Īrija, Apvienotā Karaliste, Vācija, jo tajās ir iespējas atrast darbu un algas ir vidēji četras reizes augstākas nekā Latvijā. Parasti šie jaunieši ārvalstīs netiek nodarbināti atbilstoši kvalifikācijai, viṇi tiek nodarbināti kā mazkvalificēti strādnieki. Tādā veidā valstis, no kurām emigrē jaunieši, zaudē labi izglītotus cilvēkus, bet valstis, kurās jaunieši imigrē, neizmanto viṇu zināšanas un iemaṇas vajadzīgajā līmenī. Tādā gadījumā migrācijas problēma pārtop par sociālo problēmu visā Eiropas Savienības līmenī. Pētījuma mērksis ir novērtēt un salīdzināt dažus ekonomiskos aspektus Latvijā un Slovākijā, kā arī valstīs, uz kurieni jaunieši imigrē. Pētījuma gaitā tika salīdzināti Slovākijas, Latvijas, ES, kā arī Apvienotās Karalistes, Īrijas tādu ekonomisko rādītāju dinamika, kā IKP, bruto darba algas, inflācija. Izstrādāti priekšlikumi, kas varētu mazināt intelektuālā potenciāla aizplūšanu no valstīm. Pētījuma gaitā tika izstrādāti priekšlikumi, kas nosaka, ka migrācijas problēmas risināšanai nepietiekoši ievērot tikai ekonomiskos faktorus, vajadzīga stratēgiskā pieeja nacionālā līmenī; ir nepieciešams attīstīt Cilvēkresursu attīstības programmu katrā valstī un reǵionā ar mērksi paaugstināt vietējo jauno cilvēku interesi par biznesa attīstības iespējām dzimtajā reǵionā. Kvalitatīva programmas izstrāde un tās veiksmīga ieviešana lielā mērā novērstu depopulācijas draudus regionā. Kā viens no šīs programmas virzieniem varētu būt jaunu cilvēku apmācības, kas saistītas ar reǵiona 
specializācijām un ir nodefinētas reǵionu attīstības stratēgijās. Tas palīdzētu radīt vietējo jauniešu sapratni un interesi par biznesa iespējām dzimtajā regionā.

Izvirzītā hipotēze ir apstiprinājusies: ir iespējams samazināt jauniešu emigrāciju no valsts, mainot pieeju jauniešu politikai valstī

Atslēgas vārdi: Ekonomika Latvijā un Slovākijā, nodarbinātība, minimālā alga, IKP. 